ISSN 0258-7122 (Print), 2408-8293 (Online)

Bangladesh J. Agril. Res. 41(1): 173-182, March 2016

\title{
GENETIC VARIABILITY, CHARACTER ASSOCIATION AND PATH ANALYSIS IN MAIZE (Zea mays L.)
}

\author{
S. BEGUM ${ }^{1}$, A. AHMED ${ }^{2}$, S. H. OMY ${ }^{3}$ \\ M. M. ROHMAN ${ }^{4}$ AND M. AMIRUZZAMAN ${ }^{5}$
}

\begin{abstract}
Twenty-two maize hybrids were evaluated to find out their variability, character association and path coefficient of grain yield and its component characters. Significant differences were found among the genotypes for the characters studied. Ear length and grain yield (t/ha) had moderate genotypic coefficient of variation $(\mathrm{GCV})$ and phenotypic coefficient of variation (PCV), but the had the low environmental co-efficient of variation (ECV). The heritability for all the characters was high. The characters viz. plant height, ear height and 1000-grain weight, showed high heritability along with high genetic advance. Ear length, ear diameter and kernel per row had highly significant positive correlation with grain yield. However, the deviations between genotypic and phenotypic correlation and magnitude of environmental correlation suggested considerable influence of growing environment in expressing almost all the characters. Path coefficient analysis revealed that plant height (0.659), ear length (0.934) and kernel-rows per ear (0.715) had highly significant positive direct effect on grain yield suggesting their importance during selection. Simultaneous restricted selection should be done for number of kernel rows per ear.
\end{abstract}

Keywords: Genetic variability, heritability, character association, path analysis, Zea mays.

\section{Introduction}

Maize (Zea mays L.) plays a significant role in human and livestock nutrition world-wide. Among the cereal crops over the world, maize ranks first in total production followed by wheat and rice. In Bangladesh, maize is also becoming an emerging crop and ranks the third most important cereal after rice and wheat. Currently maize is grown on about 0.31 million hectares of land with a production of 2.18 million metric tons and average yield of $6.98 \mathrm{t} / \mathrm{ha}$ (BBS, 2014).

Bangladesh Agricultural Research Institute (BARI) has been doing research on hybrid maize since 2000. However, the yield of BARI developed hybrids is slightly lower than the imported commercial varieties (Anon., 2014). Therefore, through recycling method from top yielded commercial variety $900 \mathrm{M}$, new populations are being advanced to develop new inbreds. In breeding methods, variation and

\footnotetext{
${ }^{1-3}$ Scientific Officer, Plant Breeding Division, Bangladesh Agricultural Research Institute (BARI), Gazipur-1701, ${ }^{4}$ Senior Scientific Officer, Plant Breeding Division, BARI, Gazipur-1701, ${ }^{5}$ Principal Scientific Officer, Plant Breeding Division, BARI, Gazipur1701, Bangladesh.
} 
character association are checked for fruitful selection during generation advance. Grain yield is a complex character which is highly influenced by the environment and is the result of inter-relationships of its various yield components (Grafius, 1960). Thus information on genotypic and phenotypic correlation coefficients among various plant traits help to ascertain the degree to which these are associated with economic productivity. The association between two characters can directly be observed as phenotypic correlation, while genotypic correlation expresses the extent to which two traits are genetically associated. Both genotypic and phenotypic correlations among and between pairs of agronomic traits provide scope for indirect selection in a crop breeding program (Pavan et al., 2011). Since yield components are inter-related and develop sequentially at different growth stages, correlations may not provide a clear picture of the importance of each component in determining grain yield. Path coefficient analysis provides more information among variables than correlation coefficients (Aycicek and Yildirim, 2006). Path coefficient analysis furnish a method of partitioning the correlation coefficient into direct and indirect effect and provides the information on actual contribution of a trait on the yield (Dewey and Lu, 1959). Therefore, correlation and path coefficient analysis are effective tools to improve the efficiency of breeding programs through the use of appropriate selection indices (Mohammadi et al., 2003). The present study was therefore, undertaken to derive information on variability, correlations and path coefficient among characters in newly developed $\mathrm{S}_{4}$ lines derived from commercial hybrid 900M.

\section{Materials and Method}

The experiment was conducted with 22 genotypes including $F_{1} s$ generated from crosses of selected $\mathrm{S}_{4}$ lines and four different testers viz., L22, BIL28, BIL106 and BIL110 along with three commercial checks viz., BHM 9, $900 \mathrm{M}$ and BHM 7. The crosses were produced in 2012-13 and the genotypes were evaluated at the research field of Bangladesh Agricultural Research Institute, Gazipur, during winter 201314. Each entry was raised in two rows maintaining space of $75 \mathrm{~cm} \times 20 \mathrm{~cm}$. The recommended package of production practices was followed to raise a good crop. Observations were recorded from ten randomly selected plants for each replication on days to $50 \%$ tasseling and $50 \%$ silking, plant height $(\mathrm{cm})$, ear height $(\mathrm{cm})$, ear length $(\mathrm{cm})$, ear diameter $(\mathrm{cm})$, number of kernel-rows per ear $(\mathrm{R} / \mathrm{E})$, number of kernels per row $(\mathrm{K} / \mathrm{R}), 1000$-grain weight $(\mathrm{g})$ and grain yield $(\mathrm{t} / \mathrm{ha})$. The phenotypic, genotypic, environmental variances and heritability were estimated as suggested by Lush (1940). The phenotypic, genotypic and environmental coefficients of variances were estimated as suggested by Burton (1952) and categorized as low $(>10 \%)$, moderate $(10-20 \%)$ and high $(<20 \%)$ as suggested by Sivasubramanian and Madhavamenon (1973). Heritability was calculated as suggested by Lush (1940) and categorized as low (>30\%), moderate (30-60\%) and high $(<60 \%)$ as suggested by Jonson et al. (1955). Genetic advance and genetic advance as percent of mean and phenotypic, genotypic and environmental 
correlation coefficients were worked out by following the method suggested by Jonson et al. (1955), and the range of genetic advance as per cent of mean is also classified as suggested by him as low (>10\%), moderate (10-20\%) and high $(<20 \%)$. Path analysis was carried out using the genotypic correlation coefficient as suggested by Wright (1921) and illustrated by Dewey and Lu (1959).

\section{Results and Discussion}

\section{Variability, heritability and genetic advance}

Mean performance of all genotypes was presented in Table 1. It was observed that there was a significant variation for all the characters studied in the present investigation and a scope for effective selection. Genotypic, environmental and phenotypic variation and coefficient of variation, heritability, genetic advance and genetic advance as per cent of mean and percent of coefficient of variation (CV\%) for yield and yield component traits were furnished in Table 2. Analysis of variance revealed highly significant differences for all quantitative traits. The genotypic coefficient of variation (GCV) and phenotypic coefficient of variation (PCV) for ear length and grain yield ( $t / h a)$ were moderate. The environment coefficient of variation (ECV) for the same characters was low which means the lower influence of environment on these characters. Hence, selection on the basis of phenotype can be effective for improvement of these traits. Heritability for all the characters was high, indicating the low influence of environment on the studied characters. The maximum heritability was recorded for ear length $(95 \%)$ and the minimum for kernel per row (62\%). Heritability estimates along with genetic advance are more helpful in predicting the gain under selection (Johnson et al., 1955a). In the present study, high heritability coupled with high genetic advance was recorded for plant height, ear height and 1000-grain weight indicating that the heritability is due to additive gene effects and selection may be effective for these three traits. On the other hand, days to $50 \%$ tasseling and silking and ear diameter showed high heritability but low genetic advance; reveal non-additive gene action and selection for these traits may not be effective.

\section{Correlation coefficient analysis}

Correlations (genotypic, environmental and phenotypic) of yield and yield component characters in the present investigation were presented in Table 3. In most cases, the genotypic correlation was higher than that of phenotypic correlation; reveal that association may be largely due to genetic reason (strong coupling linkage) (Sharma, 1988). Grain yield showed highly significant positive correlations with ear length, ear diameter and number of kernels per row. Similar findings were reported by Batool et al. (2012) and Zarei et al. (2012) for positive correlation of grain yield with ear length and Rafiq et al. (2010) for ear diameter and number of kernels per ear. 


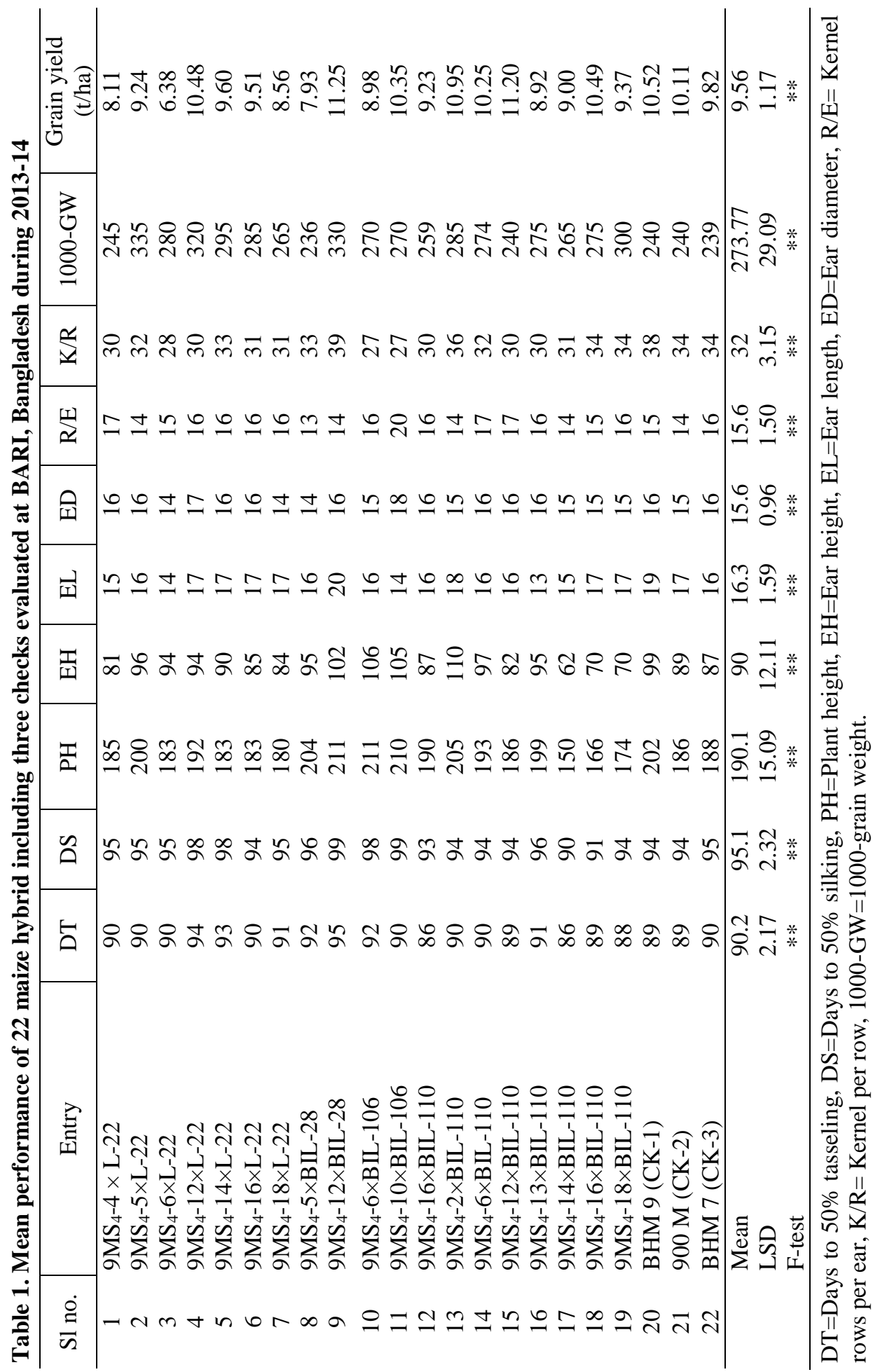




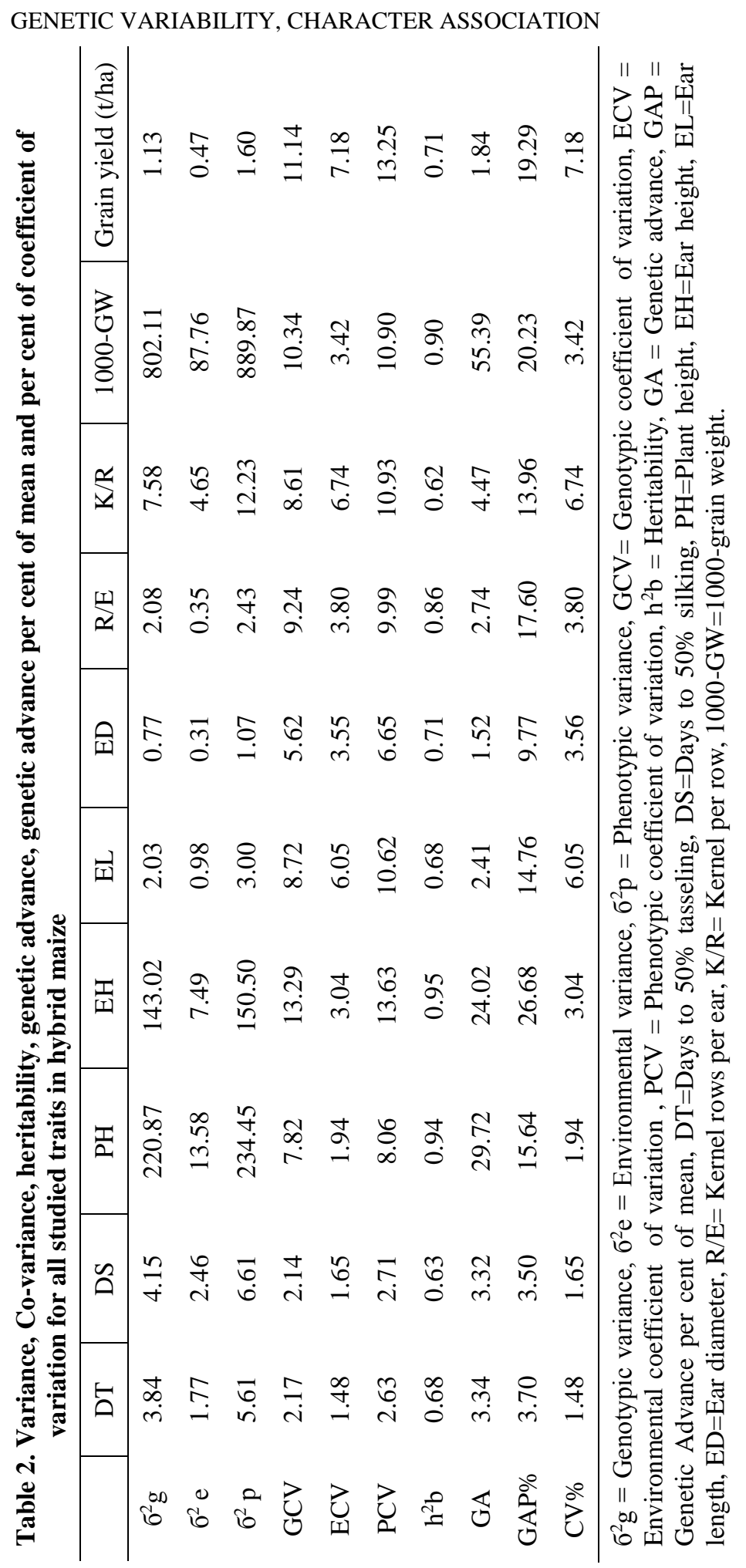




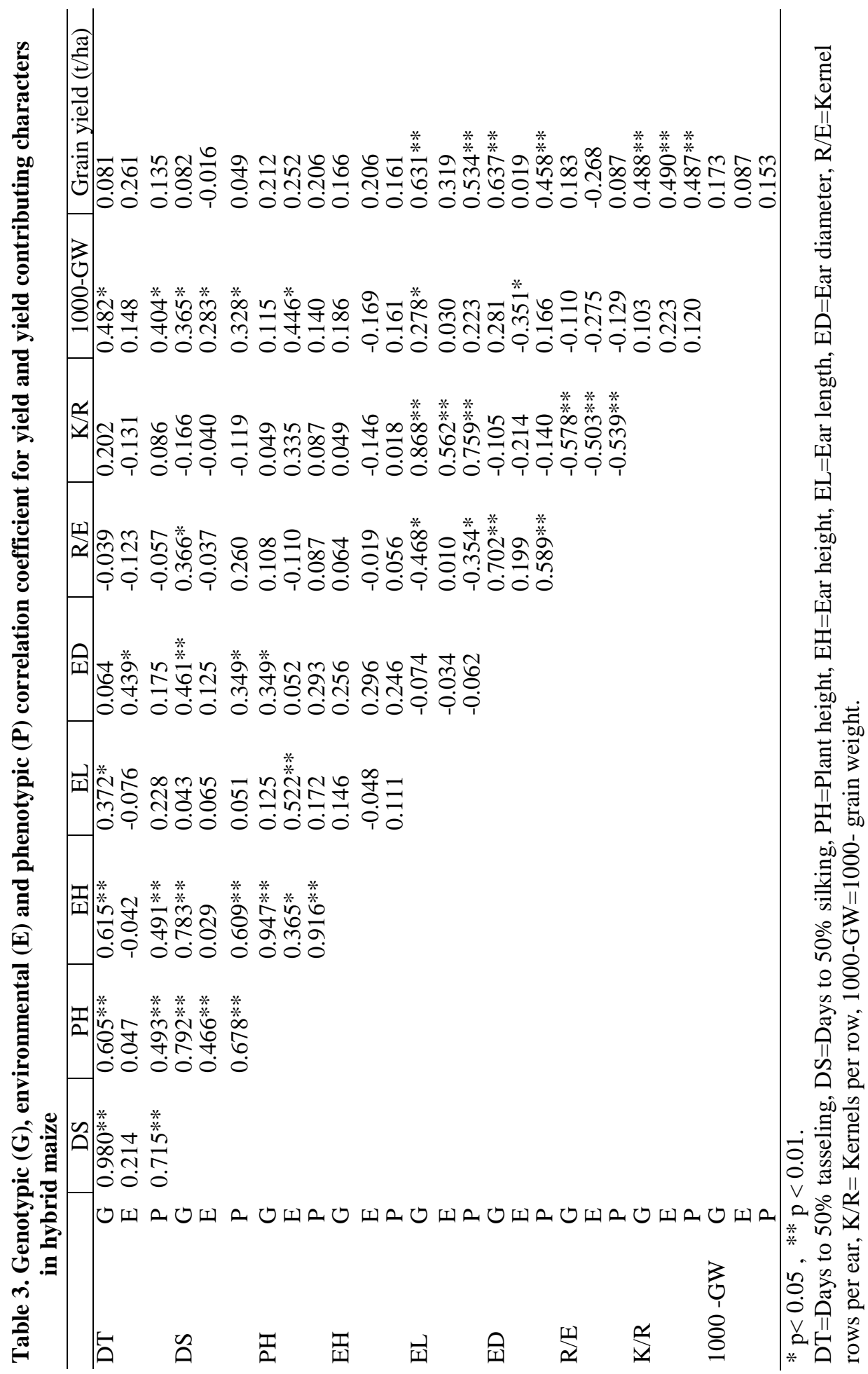




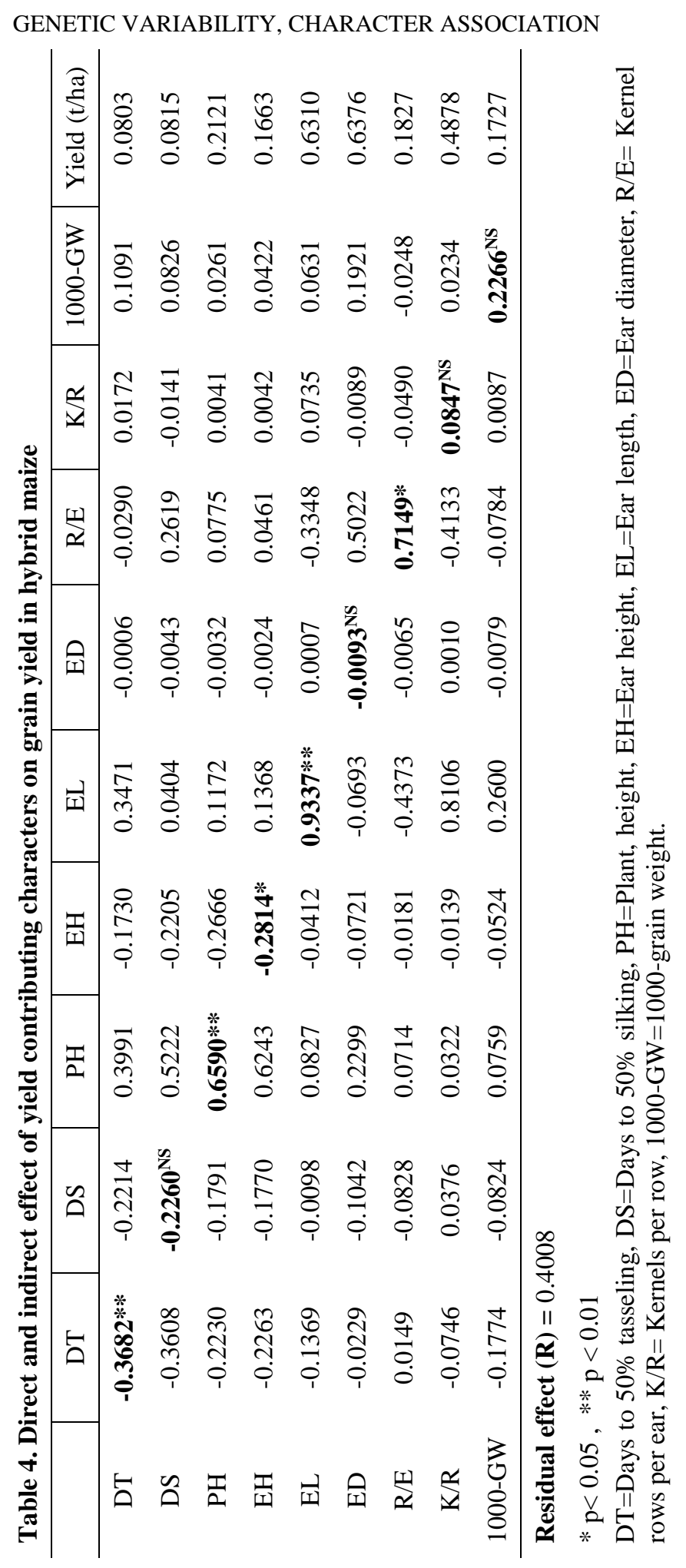


Studies on inter-character associations for yield components revealed positive and highly significant association of days to 50\% tasseling with days to 50\% silking, plant height and ear height. The result is supported by Nataraj et al. (2014). Furthermore, days to $50 \%$ silking showed highly significant positive correlation with plant and ear height, ear diameter, kernel rows per ear and 1000-grain weight. These results are in accordance with the finding of Nataraj et al. (2014). On the Contrary, Sadek et al. (2006) reported negative correlations of days to silking with 1000 kernel weight which might be due to genotypic differences. Plant height showed highly significant positive correlation with ear height. Similar result was reported by Nataraj et al. (2014). Significant positive correlation was observed among the two important yield components viz. ear length with number of kernel per row. These results are in harmony with that of Nataraj et al. (2014). Concerning ear diameter, positive correlation coefficient was found with number of rows per ear but, it was negatively correlated with number of kernel per row. Such results are in harmony with the findings of Wannows et al. (2010) who found significant and negative correlations with number of kernel per row. Similar results were reported by Khazaei et al. (2010).

\section{Path coefficient analysis}

High correlation coefficients may not be always giving the true picture or could mislead the decision because the correlation between two variables may be due to a third factor. Therefore, it is necessary to analyze the cause and effect relationship between dependent and independent variables to reveal the nature of relationship between the variables. Path coefficient analysis furnished a method of partitioning the correlation coefficient into direct and indirect effect and provides the information on actual contribution of a trait on the yield (Dewey and Lu, 1959). In the present study, direct and indirect effects of nine characters on grain yield were estimated and are presented in Table 4 . The traits having high positive correlation along with high direct effects are expected to be useful as selection criteria in improvement program (Pavan et al., 2011). In the present study, plant height, ear length and kernel rows per ear had highly significant positive direct effect on grain yield. The findings are in consonance with the reports of Pavan et al. (2011). Kernels per row and 1000-grain weight also had positive but non-significant direct effect on grain yield. Batool et al. (2012) also found that ear length had high positive direct effect on grain yield, which support the present result. On the other hand, days to 50\% tasseling, days to 50\% silking and ear height had negative direct effect on grain yield. For these characters, restricted selection should be followed. Emphasis should be given on days to 50\% tasseling, plant height and ear height should be emphasized during selection as they had positive indirect effect (Table 4). Ear height, plant height and kernel rows per ear nullify the negative direct effect therefore, for these characters, simultaneous restricted selection is suggested. Although plant height and kernel rows per ear don't have significant positive 
correlation with grain yield but these two traits had highly direct positive effect on grain yield. On the other hand, Kernel per row had highly significant positive correlation with grain yield and its direct effect on grain yield was positive but low. However, its positive effect on improving the yield was indirect through the increment of ear length.

The residual effects permit precise explanation about the pattern of interaction of other possible components of yield. The residual effect recorded was 0.4008 ; it indicates the studied characters contribute $60 \%$ of variations in yield of maize.

\section{Conclusion}

From the analysis of variability, it can be concluded that phenotypic selection for ear length and grain yield will be effective. As plant height, ear height and 1000grain weight revealed high heritability coupled with high genetic advance therefore, selection may be effective for these three traits. From correlation coefficient and path analysis, it was found that plant height, ear length and kernel rows per ear had positive correlation coefficient with grain yield and had high direct positive effect on yield. Though number of kernels per row had low positive direct effect on grain yield, it had highly significant positive correlation coefficient with grain yield. Similarly though ear diameter had low negative direct effect on yield, it had highly significant positive correlation coefficient with grain yield. Thus selection for these characters could be considered as important criteria in improving grain yield of maize.

\section{References}

Anonymous, 2014. Annual research report for 2013-14, Plant Breeding Division, Bangladesh Agricultural Research Institute, Gazipur-1701, P. 115

Aycicek, M. and T. Yildirim. 2006. Path coefficient analysis of yield and yield components in bread wheat (Triticum aestivum L.) genotypes. Pak. J. Bot. 38(2): 417-424.

Batool, Z., K. Danial, P. A. Alireza, and S. Farhad. 2012. Correlation and path coefficient analysis for determining interrelationships among grain yield and related characters in corn hybrids (Zea mays L). Intl. J. Agri. Crop Sci. 4(20), 1519-1522.

BBS. 2014. Statistical Pocket Book of Bangladesh (Bangladesh Burea of Statistics), Ministry of Planning, Government of the People Republic of Bangladesh, P. 203.

Burton, G.W. 1952. Quantitative inheritance in grasses. Proc. $6^{\text {th }}$ Int. Grassland Cong. 1:227-283.

Dewey, D, R. and K. H. Lu. 1959. A correlation and path coefficient analysis of component of crested wheat grass seed production. Agron. J. 51: 515-518.

Grafius, J. E. 1960. Does over dominance exist for yield in corn? Agron. J. 52: 361.

Johnson, H. W., H. F. Robinson and R. E. Comstock. 1955. Estimates of genetic and environmental variability in soyabean. Agron. J. 47: 314-318. 
Khazaei, F., M. A. Alikhani, L. Yariand and A. Khandan. 2010. Study the correlation, regression and path coefficient analysis in sweet corn (Zea mays var. Saccharata) under different levels of plant density and nitrogen rate. ARPN J. of Agri. Biol. Sci. 5(6): 14-19

Lush, J. L. 1940.Intra-sire correlation and regression of offspring in rams as a method of estimating heritability of characters. Proc. Amer. Soc. Animal Product. 33: 292-301.

Mohammadi, S. A., B. M. Prasanna and N. N. Singh. 2003. Sequential path model for determining interrelationships among grain yield and related characters in maize. Crop Sci. 43: 1690-1697.

Nataraj, V., J. P. Shahi and V. Agarwal. 2014. Correlation and path analysis in certain inbred genotypes of maize (Zea Mays L.) at Varanasi. Intl. J. Inno. Res. \& Dev. 3(1):14-17.

Pavan R., H. C. Lohithaswa, M. C. Wali, G. Prakash and B. G. Shekara. 2011. Correlation and path coefficient analysis of grain yield and yield contributing traits in single cross hybrids of maize (Zea mays L.). Electronic J. Pl. Breed. 2(2):253-257.

Rafiq, C. M., M. Rafique, A. Hussain and A. Altaf. 2010. Studies on heritability, correlation and path analysis in maize (Zea mays L.). J. Agri. Res. 48 (1): 35-38.

Sadek, S. E., M. A. Ahmed and H. M. Abd El-Ghaney. 2006. Correlation and path coefficient analysis in five parents inbred lines and their six white maize (Zea mays L.) single crosses developed and grown in Egypt. J. App. Sci. Res. 3: 159-167.

Sharma, J. R. 1988. Statistical and biometrical techniques in plant breeding. New age international (Pvt) Ltd., New Delhi. Reprint: 2008: P. 35.

Sivasubramanian, V. and P. Madhavamenon. 1973. Path analysis for yield and yield components of rice. Madras Agric. J. 60: 1217-1221.

Wannows, A.A, H. K. Azzam and S. A. AL- Ahmad. 2010. Genetic variances, heritability, correlation and path coefficient analysis in yellow maize crosses (Zea mays L.). Agric. Biol. J. N. Am. 1(4): 630-637.

Wright, S. 1921. Correlation and causation.J. Agric. Res. 20: 557-585

Zarei, B., D. Kahrizi, A. P. Aboughadaresh and F. Sadeghi. 2012. Correlation and path coefficient analysis for determining interrelationships among grain yield and related characters in corn hybrids. Intl. J. Agri. \& Crop Sci. (IJACS). 4 (20): 1519-152. 